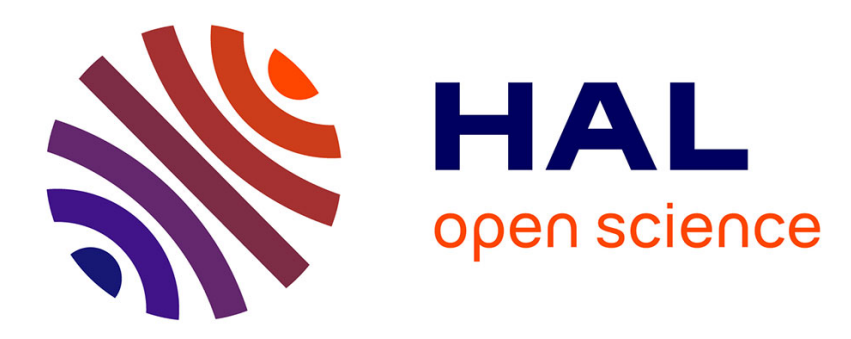

\title{
Study of oilwell cements by solid-state NMR
}

\author{
Gwenn Le Saoût, Éric Lécolier, Alain Rivereau, Hélène Zanni
}

\section{To cite this version:}

Gwenn Le Saoût, Éric Lécolier, Alain Rivereau, Hélène Zanni. Study of oilwell cements by solidstate NMR. Comptes Rendus. Chimie, 2004, 7 (3-4), pp.383-388. 10.1016/j.crci.2003.10.018 . hal03251324

\section{HAL Id: hal-03251324 \\ https://hal.science/hal-03251324}

Submitted on 7 Jun 2021

HAL is a multi-disciplinary open access archive for the deposit and dissemination of scientific research documents, whether they are published or not. The documents may come from teaching and research institutions in France or abroad, or from public or private research centers.
L'archive ouverte pluridisciplinaire HAL, est destinée au dépôt et à la diffusion de documents scientifiques de niveau recherche, publiés ou non, émanant des établissements d'enseignement et de recherche français ou étrangers, des laboratoires publics ou privés. 


\title{
Study of oilwell cements by solid-state NMR
}

\author{
Gwenn Le Saoût ${ }^{\mathrm{a}, \mathrm{b}, *}$, Éric Lécolier ${ }^{\mathrm{a}}$, Alain Rivereau ${ }^{\mathrm{a}}$, Hélène Zanni ${ }^{\mathrm{b}}$ \\ a Institut français du pétrole, 1-4, av. de Bois-Préau, 92852 Rueil-Malmaison, France \\ ${ }^{b}$ Laboratoire de physique et mécanique des milieux hétérogènes, UMR CNRS 7636, ESPCI, \\ 10, rue Vauquelin, 75231 Paris cedex 05, France
}

\begin{abstract}
The prime objective of the plug-and-abandon operations is to provide zonal isolation for infinite time. Cement-based materials are generally used as plugging materials. Therefore, it is important to understand physical and chemical processes causing cement degradation in downhole environment. In this study, we have characterised two cement formulations at different ageing conditions using NMR and XRD techniques. In particular, we evidence that an increase in pressure and temperature leads to more polymerised calcium silicate hydrates $(\mathrm{C}-\mathrm{S}-\mathrm{H})$. In the low permeability cement samples, it was shown that the pozzolanic activity of silica fumes increases with temperature and pressure and leads to the consummation of all the portlandite released during cement hydration.
\end{abstract}

\section{Résumé}

L'objectif d'une opération d'abandon de puits est d'établir une zone d'isolation pour une durée infinie. Les bouchons mis en place pour fermer les puits sont majoritairement des bouchons de ciment. Il est donc important de comprendre les différents processus physiques et chimiques de la dégradation du ciment dans les conditions de puits. Dans cette étude, nous avons caractérisé la structure de deux formulations dans différentes conditions de vieillissement, en utilisant les techniques de RMN et de DRX. Nous avons pu montrer que l'augmentation de pression et de température conduisait à une polymérisation plus importante des silicates de calcium hydratés $(\mathrm{C}-\mathrm{S}-\mathrm{H})$. Dans le cas des ciments de faible perméabilité, nous avons mis en évidence une accélération de l'activité pouzzolanique de la fumée de silice lorsque la température et la pression augmentent.

Keywords: Oilwell cements; XRD; NMR

Mots clés : Ciments pétroliers ; DRX ; RMN

\footnotetext{
* Corresponding author.

E-mail address: lesaout@pmmh.espci.fr (G. Le Saoût).
} 


\section{Introduction}

Wells have been drilled for different purposes: exploration, disposal, oil and gas production... All these wells will be abandoned and will require plugging. The goal of each well abandonment should be to control any leakage of fluids within the well to avoid the risk of contamination of freshwater aquifer and to monitor the state of well sealing in order to prevent surface or sea pollution [1]. Many formulations have been developed for oilwell cementation; however, only few studies have been devoted to the physical and chemical processes causing cement degradation under downhole conditions [2-5].

The objective of this work is to study the structure and the properties of cement formulations cured and stored under different conditions of temperature and pressure. The XRD allows us to investigate the highly crystallized phase, whereas NMR is very adapted to the study of such heterogeneous and multiple phase material [6]. It is also one of the only available techniques able to investigate the calcium silicate hydrates $(\mathrm{C}-\mathrm{S}-\mathrm{H})$, which are the main constituents of the Portland cement paste. It is well known that $\mathrm{C}-\mathrm{S}-\mathrm{H}$ present a poorly crystalline structure and variable composition [7].

\section{Experimental details}

Two cement formulations, a class G Portland cement (labelled $\mathrm{C}$ in the text) and a Low Permeability Cement (LPC), with two curing conditions were prepared for this study as described in Table 1 . The unhydrated cement used was a class-G Portland cement from the Dyckerhoff Company (Bogue composition (wt\%): $51.2 \mathrm{Ca}_{3} \mathrm{SiO}_{5}, 27 \mathrm{Ca}_{2} \mathrm{SiO}_{4}, 2.3 \mathrm{Ca}_{3} \mathrm{Al}_{2} \mathrm{O}_{6}$, 14.4 $\left.\mathrm{Ca}_{4} \mathrm{Al}_{2} \mathrm{Fe}_{2} \mathrm{O}_{10}\right)$. In the case of LPC samples, sand and silica fume were added to the class-G Portland cement to increase mechanical and durability properties by optimising the material compacity [8]. The addition of silica fume produces secondary hydrates by pozzolanic reaction with the lime resulting from primary hydration $\left(\mathrm{SiO}_{2}+\mathrm{Ca}(\mathrm{OH})_{2} \rightarrow \mathrm{C}-\mathrm{S}-\mathrm{H}\right)$ [9]. Silica fume has a very high water demand, because of its high specific-surface area, so a cement-dispersant, polynaphtalene sulfonate (PNS), was incorporated in the mixes to maintain adequate consistency at a reasonable water/cement ratio.

$\mathrm{X}$-ray diffraction (XRD) data were collected using a Philips PW 1820 diffractomer employing the Co-K $\alpha$ radiation $\left(\lambda_{0}=1.789 \AA\right)$. The samples were scanned at $0.6^{\circ}$ per minute between 2 and $82^{\circ} 2 \theta$.

The ${ }^{27} \mathrm{Al}$ and ${ }^{29} \mathrm{Si} \mathrm{NMR}$ experimental details are reported in Table 2. Single-pulse experiments were carried out in order to respect the relaxation times of

Table 1

Characteristics of cement mixes (weight ratios relative to cement mass) and curing conditions

\begin{tabular}{|c|c|c|c|c|}
\hline Formulations & & & & \\
\hline Components & LPC I & LPC II & C I & C II \\
\hline Cement class $\mathrm{G}$ & 1 & & 1 & \\
\hline Silica fume & 0.24 & & - & \\
\hline Sand & 0.2 & & - & \\
\hline Cement dispersant & 0.018 & & - & \\
\hline Water & 0.27 & & 0.44 & \\
\hline Curing conditions ( 30 days in tap water) & $\begin{array}{l}T=293 \mathrm{~K} \\
p=10^{5} \mathrm{~Pa}\end{array}$ & $\begin{array}{l}T=353 \mathrm{~K} \\
p=7 \times 10^{6} \mathrm{~Pa}\end{array}$ & $\begin{array}{l}T=293 \mathrm{~K} \\
p=10^{5} \mathrm{~Pa}\end{array}$ & $\begin{array}{l}T=353 \mathrm{~K} \\
p=7 \times 10^{6} \mathrm{~Pa}\end{array}$ \\
\hline
\end{tabular}

Table 2

Experimental details for NMR measurements

\begin{tabular}{|c|c|c|c|c|c|c|c|}
\hline Nucleus & Sample & Spectrometer Bruker & $\begin{array}{l}\mathrm{ZrO}_{2} \\
\text { rotor }\end{array}$ & $\begin{array}{l}\text { Frequency } \\
(\mathrm{MHz})\end{array}$ & Pulse width & $\begin{array}{l}\text { Relaxation } \\
\text { delay (s) }\end{array}$ & $\begin{array}{l}\text { Spinning rate } \\
(\mathrm{kHz})\end{array}$ \\
\hline${ }^{27} \mathrm{Al}$ & LPC, $\mathrm{C}$ and raw materials & ASX 500 & $2.5 \mathrm{~mm}$ & 129.80 & $\pi / 12(0.5 \mu \mathrm{s})$ & 1 & 25 \\
\hline \multirow[t]{2}{*}{${ }^{29} \mathrm{Si}$} & LPC & $11.7 \mathrm{~T}$ & $7 \mathrm{~mm}$ & 99.305 & $\pi / 2$ & 60 & 5.5 \\
\hline & $\mathrm{C}$ and raw materials & $\begin{array}{l}\text { ASX } 300 \\
7.05 \mathrm{~T}\end{array}$ & $4 \mathrm{~mm}$ & 59.591 & & 3 & 7 \\
\hline
\end{tabular}


the species present in the samples except for sand. The ${ }^{27} \mathrm{Al}$ and ${ }^{29} \mathrm{Si}$ chemical shifts were respectively referenced relative to a $1.0 \mathrm{M} \mathrm{AlCl}_{3}-6 \mathrm{H}_{2} \mathrm{O}$ solution and to tetramethylsilane $\mathrm{Si}\left(\mathrm{CH}_{3}\right)_{4}$ (TMS) at $0 \mathrm{ppm}$, using $\mathrm{Si}\left[\left(\mathrm{CH}_{3}\right)_{3}\right]_{8} \mathrm{Si}_{8} \mathrm{O}_{20}(\mathrm{Q} 8 \mathrm{M} 8)$ as a secondary reference (the major peak being at $11.6 \mathrm{ppm}$ relatively to TMS).

\section{Results and discussion}

\subsection{X-ray diffraction}

Phases identification of hardened cements after a 30 days-cure at ambient temperature and atmospheric pressure by XRD analysis (Fig. 1) shows the presence of unhydrated phases alite $\mathrm{Ca}_{3} \mathrm{SiO}_{5}$, belite $\mathrm{Ca}_{2} \mathrm{SiO}_{4}$, ferrite phase $\mathrm{Ca}_{2}\left(\mathrm{Al}_{x} \mathrm{Fe}_{1-x}\right)_{2} \mathrm{O}_{5}$ (where $0<x<0.7$ ) along with $\alpha$-quartz due to siliceous aggregate used in LPC samples and usual hydrated phases such as port-

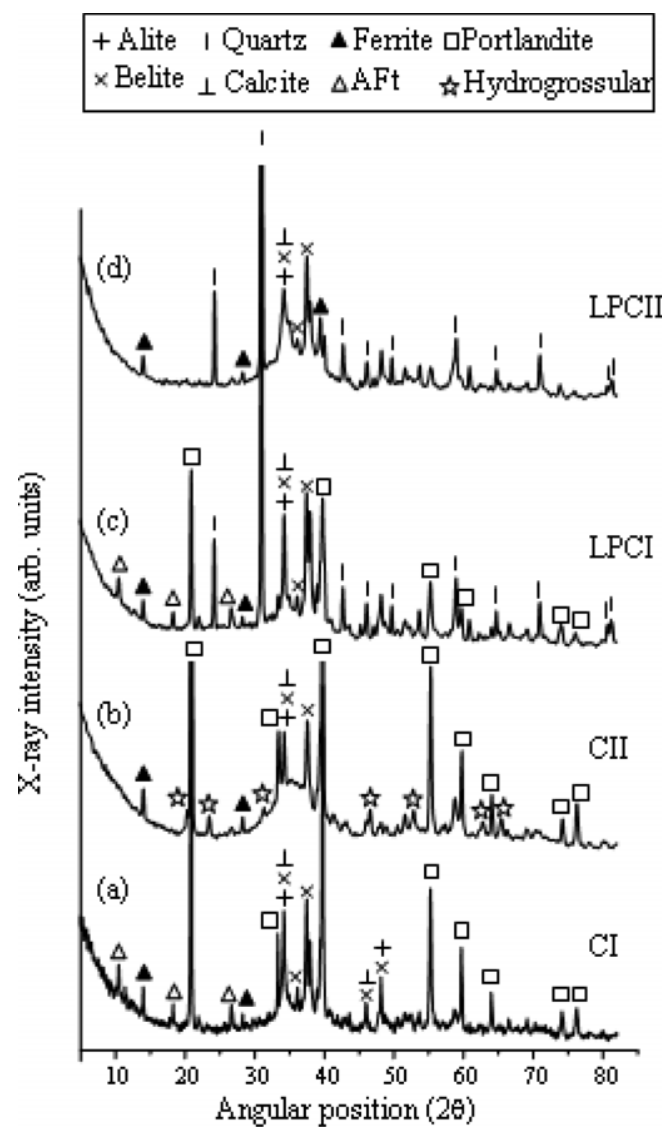

Fig. 1. XRD patterns of samples hydrated for 30 days at (a, c): $T=293 \mathrm{~K}, p=10^{5} \mathrm{~Pa}$ and $(\mathbf{b}, \mathbf{d}): T=353 \mathrm{~K}, p=7 \times 10^{6} \mathrm{~Pa}$, Co K $\alpha$ radiation. landite $\mathrm{Ca}(\mathrm{OH})_{2}$, and ettringite $\left[\mathrm{Ca}_{3} \mathrm{Al}(\mathrm{OH})_{6} \cdot 12\right.$ $\mathrm{H}_{2} \mathrm{O}_{2} \cdot\left(\mathrm{SO}_{4}\right)_{3} \cdot 2 \mathrm{H}_{2} \mathrm{O}$ (AFt phase). In the samples cured at high temperature and high pressure, ettringite phase was absent. In the CII sample, instead ettringite, hydrogrossular $\mathrm{CaO}_{3} \mathrm{Al}_{2} \mathrm{O}_{3}\left(\mathrm{SiO}_{2}\right)_{3-x}\left(\mathrm{H}_{2} \mathrm{O}\right)_{2 x}$ (where $x=0$ to 3 ) have been formed. Under conditions of elevated temperature, previous studies have shown that hydrogrossular Si-free will form, which is the most thermodynamically stable and the least soluble of the calcium aluminate hydrates [10]. In the LPCII spectra, all peaks characterising the portlandite phase $\left[\mathrm{Ca}(\mathrm{OH})_{2}\right]$ have completely disappeared. The calcium hydroxide released during cement hydration is actually consumed as a result of interaction with active silica fume to form $\mathrm{C}-\mathrm{S}-\mathrm{H}$ phases.

\subsection{Magic Angle Spinning Nuclear Magnetic Resonance Spectroscopy}

\subsection{1. ${ }^{29} \mathrm{Si}$ MAS NMR}

An example of the spectra decomposition is presented in Fig. 2d, where we have also reported NMR spectra of the raw materials (Fig. 2a-c). It is important

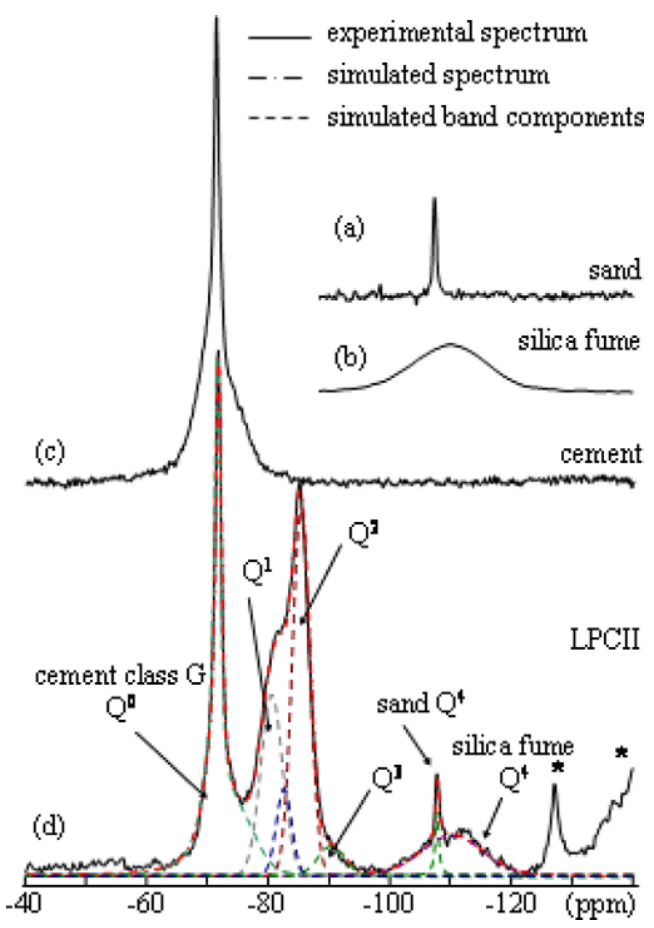

Fig. 2. ${ }^{29}$ Si MAS NMR spectra of raw materials: (a) sand, (b) silica fume, (c) cement, and (d) LPCII sample hydrated for 30 days at $T=353 \mathrm{~K}$ and $p=7 \times 10^{6} \mathrm{~Pa}$ with its deconvoluted peaks. The asterisks mark spinning sidebands. 
to note that even though the presence of Fe can cause peak broadening and the Fe-content of oilwell Portland cement is quite large, reasonably well-defined spectra can be obtained. The ${ }^{29} \mathrm{Si}$ NMR spectrum in Fig. 2a displays a narrow line of $\mathrm{Q}^{4}$ type at $-107 \mathrm{ppm}$ and is characteristic of crystalline quartz, whereas the broad peak at $-110 \mathrm{ppm}$ in the spectrum for silica fume (Fig. 2b) is characteristic of amorphous $\mathrm{SiO}_{2}$. Fig. 2c shows the ${ }^{29} \mathrm{Si} \mathrm{NMR}$ spectrum of class-G cement. It contains a broad $\mathrm{Q}^{0}$ component near $-71 \mathrm{ppm}$, which is the sum of alite and belite. The observed line broadening arises from the incorporation of metal $\left(\mathrm{Mg}^{2+}, \mathrm{Al}^{3+}\right.$ and $\mathrm{Fe}^{3+}$ ) and other impurity ions into the crystal lattice [11]. All raw materials are still present in the hydrated cement (Fig. 2d) with usual nonstoichiometric and non-crystalline calcium silicate hydrates $(\mathrm{C}-\mathrm{S}-\mathrm{H})$. The main resonance lines at $-79.2 \mathrm{ppm}$ and $-85.5 \mathrm{ppm}$ are respectively due to the end-chain tetrahedra $\mathrm{Q}^{1}$ and nonbridging tetrahedra $\mathrm{Q}^{2}$ of the $\mathrm{C}-\mathrm{S}-\mathrm{H}$ [12]. The peak for $\mathrm{Q}^{2}$ sites is asymmetric or has a small shoulder at about $-82.5 \mathrm{ppm}$. In calcium silicate hydrate, this peak has been already assigned to the middle tetrahedral of the dreierkette $\mathrm{C}-\mathrm{S}-\mathrm{H}$ chain structure $\left(\mathrm{Q}_{\mathrm{L}}^{2}\right)[13,14]$, to distorted $\mathrm{Q}^{2}$ sites produced by various kinds of staking disorder [15] or to $\mathrm{Q}^{2}$ species originating from precipitation of hydrate from the small quantities of bleed water resulting from the large centrifugal forces induced by the MAS technique [16]. Furthermore, in our samples, the $\mathrm{C}-\mathrm{S}-\mathrm{H}$ can also contain $\mathrm{Al}$ and the $\mathrm{Q}^{2}(1 \mathrm{Al})$ are expected in the same shift range as the $\mathrm{Q}_{\mathrm{L}}^{2}$ [17]. Thus, assignment of this peak is a difficult problem that remains unresolved. The $\mathrm{Q}^{3}$ peak observed only as a shoulder near $-90 \mathrm{ppm}$ is ascribed to the cross-linked $\mathrm{C}-\mathrm{S}-\mathrm{H}$ structure [18].

The ${ }^{29} \mathrm{Si}$ MAS NMR spectra of C and LPC samples are presented in Fig. 3. As temperature and pressure increase, the relative intensity of the $\mathrm{Q}^{0}$ peak decreases. This is linked to an acceleration of the hydration kinetics with temperature and pressure, the $\mathrm{Q}^{0}$ anhydrous species being transformed into calcium silicate hydrate $(\mathrm{C}-\mathrm{S}-\mathrm{H})$. Furthermore, the ratio $\mathrm{Q}^{2} / \mathrm{Q}^{1}$ increases with temperature and pressure. In addition, there may be some $\mathrm{Q}^{3}$ sites present in the treated samples. These results indicate that increasing temperature and pressure increases the polymerisation of the $\mathrm{C}-\mathrm{S}-\mathrm{H}$ structure. Such structural changes have been previously observed on hydration of tricalcium silicate at high temperatures and high pressure [19].

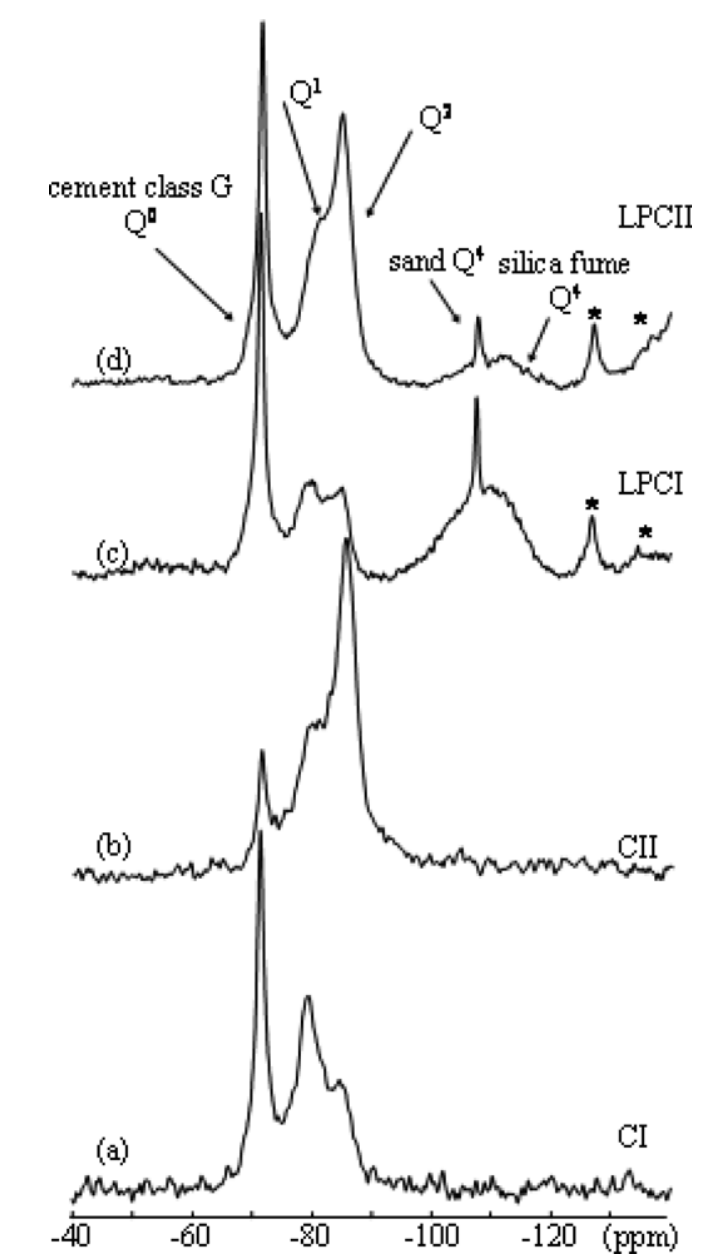

Fig. $3 .{ }^{29}$ Si MAS NMR spectra of samples hydrated for 30 days at (a, c): $T=293 \mathrm{~K}, p=10^{5} \mathrm{~Pa}$ and $(\mathbf{b}, \mathbf{d}): T=353 \mathrm{~K}, p=7 \times 10^{6} \mathrm{~Pa}$. The asterisks mark spinning sidebands.

In the case of LPC samples, we can observe an important decrease of the relative intensity of the silica fume peak with increasing temperature and pressure. This phenomenon can be attributed to the progression of the pozzolanic activity of silica fume and is in good accordance with the disappearance of portlandite in XRD spectra of the LCPII sample. This result is in agreement with studies by Zanni et al. that indicate a weak and low activity of the silica fume at ambient temperature, which increases with temperature [20].

\subsection{2. ${ }^{27}$ Al MAS NMR}

The main part of the bulk $\mathrm{Al}_{2} \mathrm{O}_{3}$ content in Ordinary Portland Cement is present in the so-called interstitial material, which contains the aluminate and ferrite 
phases. However, for oilwell cements that contain a low bulk $\mathrm{Al}_{2} \mathrm{O}_{3}: \mathrm{Fe}_{2} \mathrm{O}_{3}$ ratio, the aluminate phase is usually absent or present in very small quantities and $\mathrm{Al}$ is mainly in the ferrite phase [21].

The ${ }^{27} \mathrm{Al}$ NMR spectrum of anhydrous cement (Fig. 4a) shows a broad asymmetric band of intensity near $80 \mathrm{ppm}$ corresponding to tetrahedrally coordinated Al. The peaks near $13 \mathrm{ppm}$ and $10 \mathrm{ppm}$ are attributed to $\mathrm{Al}$ in octahedral sites. The coordination environment of aluminium in anhydrous cement is variable; anhydrous cement may contain both octahe-

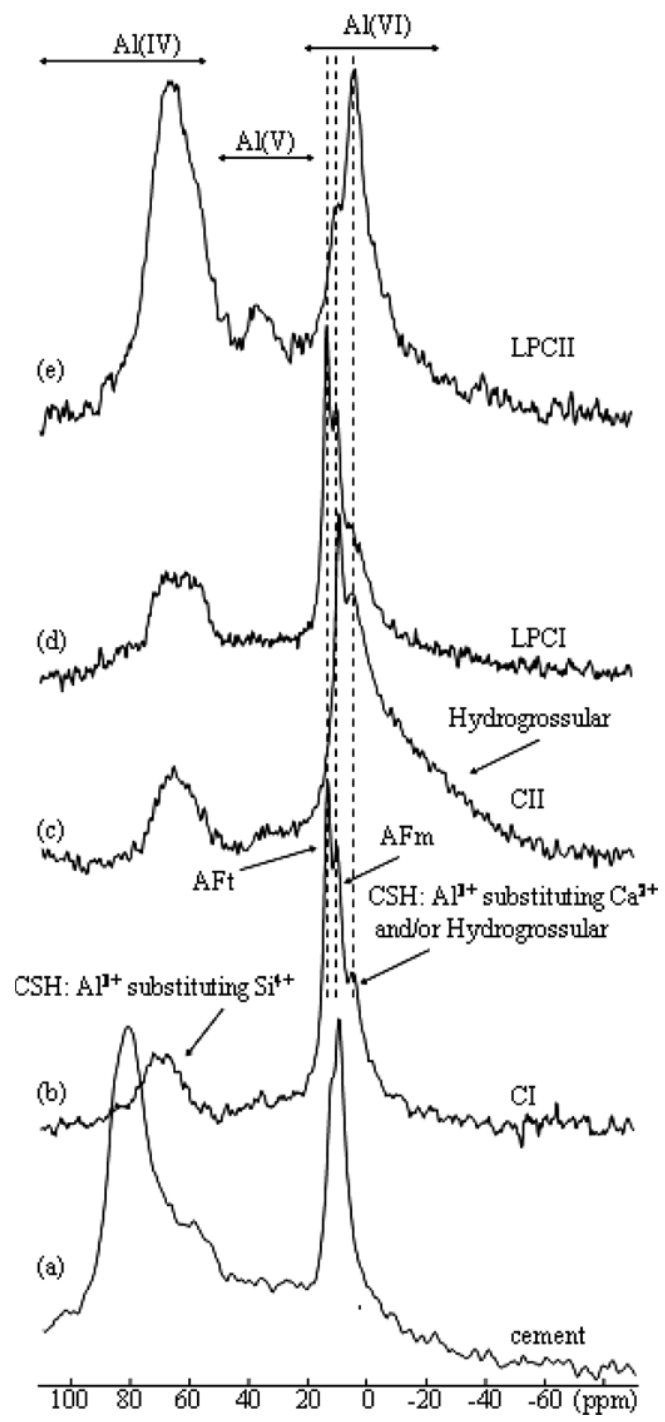

Fig. 4. ${ }^{27}$ Al MAS NMR spectra of (a) anhydrous cement and samples hydrated for 30 days at $(\mathbf{b}, \mathbf{d}): T=293 \mathrm{~K}, \mathrm{p}=10^{5} \mathrm{~Pa}$ and $(\mathbf{c}, \mathbf{e})$ : $T=353 \mathrm{~K}, p=7 \times 10^{6} \mathrm{~Pa}$ dral and tetrahedral sites or only tetrahedral sites $[11,18]$. However, octahedral sites observed may be assigned to hydration product during storage. Skibsted et al. [22] provides compelling evidence that the resonances in the tetrahedral region arise from $\mathrm{Al}$ for $\mathrm{Si}$ substitution in the alite and belite phases. They also show that $\mathrm{Al}$ present in the tetracalcium aluminoferrite phase of cement, either in the antiferromagnetic or the paramagnetic form, contributes little or no to the observed ${ }^{27} \mathrm{Al}$ MAS NMR spectrum [23]. On reaction with water, it initially forms ettringite $\left[\mathrm{Ca}_{3} \mathrm{Al}(\mathrm{OH})_{6} \cdot 12\right.$ $\mathrm{H}_{2} \mathrm{O}_{2} \cdot\left(\mathrm{SO}_{4}\right)_{3} \cdot 2 \quad \mathrm{H}_{2} \mathrm{O}$ (AFt phase) and later the thermodynamically stable monosulfoaluminate $\left[\mathrm{Ca}_{2} \mathrm{Al}(\mathrm{OH})_{6}\right]_{2} \cdot\left(\mathrm{SO}_{4}\right) \cdot 12 \mathrm{H}_{2} \mathrm{O}$ (AFm phase), which all exclusively contain octahedrally coordinated $\mathrm{Al}$ [24] and leads to peaks in ${ }^{27} \mathrm{Al} \mathrm{NMR}$ spectra respectively at 13 and $10 \mathrm{ppm}[17,22,25]$. We can notice that AFm phases are not detected by XRD, indicating that the AFm material is poorly crystalline. Taylor has suggested that AFm phases could be incorporated within the $\mathrm{C}-\mathrm{S}-\mathrm{H}$, perhaps within or near the silicate layers [24]. The peak attributed to AFm is present in all our samples but the AFt peak is not or weakly present in treated samples CII and LPCII.

We can also notice the presence of a band at $4 \mathrm{ppm}$, particularly intense in the LPCII sample and a broad band near $-20 \mathrm{ppm}$ in the CII sample. The broadest line near $-20 \mathrm{ppm}$ has been attributed to hydrogrossular phases [17]. The important width of this band can be explained by the highly distortion of site because of Si-site partial substitution by $\mathrm{OH}$ and $\mathrm{Al}$-site by iron. This attribution is in agreement with XRD results that show the presence of hydrogrossular phases in the CII sample. The attribution of the peak at $4 \mathrm{ppm}$ is not clear and has been also assigned to hydrogrossular [25], but in the investigations of aluminium incorporation in the $\mathrm{C}-\mathrm{S}-\mathrm{H}$, this peak has been assigned to $\mathrm{Al}^{3+}$ substituting $\mathrm{Ca}^{2+}$ in the octahedral sheet of the $\mathrm{C}-\mathrm{S}-\mathrm{H}$ structure [26]. However, as Taylor pointed out, the large difference in ionic radius between $\mathrm{Al}^{3+}$ and $\mathrm{Ca}^{2+}$ makes unlikely that $\mathrm{Al}^{3+}$ would replace $\mathrm{Ca}^{2+}$ randomly. Taylor proposed that $\mathrm{Al}$ replacement of $\mathrm{Ca}^{2+}$ could only occur with the formation of AFm or other phases in which $\mathrm{Al}$ is octahedrally coordinated, leaving the C-S-H with very limited substitution [24].

In sample LPCII, a band is clearly detected near $36 \mathrm{ppm}$ and tentatively assigned by Faucon et al. to pentacoordinated $\mathrm{Al}^{3+}$ substituting for $\mathrm{Ca}^{2+}$ ions situ- 
ated in the interlayers of the $\mathrm{C}-\mathrm{S}-\mathrm{H}$ structure [26]. The MAS spectra of the hydrated samples (Fig. 4b-e) also yield signal in the $\mathrm{Al}(\mathrm{IV})$ range particularly intense in the LPCII sample, but the peak maximum has changed to about $+65 \mathrm{ppm}$ from $+82 \mathrm{ppm}$ for the unhydrated cement. According to Skibsted et al. [23], the more shielded peak may arise from $\mathrm{Al}$ incorporated in the $\mathrm{C}-\mathrm{S}-\mathrm{H}$.

\section{Conclusion}

Two cement formulations with different curing conditions were analysed by XRD and NMR measurements. The raw materials are still present in all the samples hydrated one month. The increase of pressure and temperature lead to a more polymerised $\mathrm{C}-\mathrm{S}-\mathrm{H}$. In the cement $\mathrm{C}$, we observed an acceleration of the hydration kinetics with temperature and pressure. The hydrated phases of the CI sample consisted of poorly crystalline $\mathrm{C}-\mathrm{S}-\mathrm{H}, \mathrm{AFm}$ with $\mathrm{AFt}$ and portlandite. In the sample cured at $353 \mathrm{~K}, 7 \times 10^{5} \mathrm{~Pa}$, AFt phase is absent; hydrogrossular had formed instead. In the LPC samples, it was shown that the pozzolanic activity of silica fumes increases with temperature and pressure and lead to the consummation of all the portlandite released during cement hydration. This feature is quite important and positive for long-term durability aspects. Indeed, it is well known that calcium hydroxide is easily soluble as soon as $\mathrm{pH}$ is lower than 12.5 at room temperature. In order to have a better characterisation of the minor phases present in the cement, selective dissolution is underway. Furthermore, mechanical tests and porosity measurements are in progress to try to establish a correlation between the structure and macroscopic properties.

\section{Acknowledgements}

The authors would like to thank 'Institut français du pétrole' for the permission to publish this paper. They are grateful to Annie Audibert for valuable discussions, and Bernadette Rebours, Sylvie Massot, Isabelle Clémençon for their help in XRD measurements.

\section{References}

[1] I. Barclay, J. Pallenbarg, F. Tettero, J. Pfeiffer, H. Slater, T. Staal, D. Stiles, G. Tilling, C. Whitney, Oilfield Rev. 13 (2001) 28.
[2] E. Grabowski, J.-E. Gillot, Cem. Concr. Res. 19 (1989) 333.

[3] C. Noïk, A. Rivereau, C. Vernet, paper SPE 50589 presented at the SPE European Petroleum Conference, The Hague, The Netherlands, October 1998, pp. 20-22.

[4] C. Noïk, A. Rivereau, paper SPE 56538 presented at the SPE Annual Technical Conference and Exhibition, Houston, Texas, 3-6 October 1999.

[5] Z. Krilov, B. Loncaric, Z. Miksa, paper SPE 58771 presented at the SPE International Symposium on Formation Damage Control, Lafayette, Louisiana, 23-24 February 2000.

[6] H. Zanni, R. Rassem-Bertolo, L. Fernandez, S. Masse, P. Nieto, Bull. Lab. Phys. Chim. 195 (1995) 61.

[7] Z. Xu, D. Viehland, Phys. Rev. Lett. 77 (1996) 952.

[8] C. Noïk, A. Rivereau, C. Vernet, Patent EP 0950034 B1, 1999.

[9] P. Richard, M. Cheyrezy, Cem. Concr. Res. 25 (1995) 1501.

[10] P. Garcés, E.G. Alcocel, S. Chinchon, C.G. Andreu, J. Alcaide, Cem. Concr. Res. 27 (1997) 1343.

[11] J. Hjorth, J. Skibsted, H.J. Jakobsen, Cem. Concr. Res. 18 (1988) 789 .

[12] G.M. Bell, J. Bensted, F.P. Glasser, E.E. Lachowski, D.R. Roberts, M.J. Taylor, Adv. Cement Res. 3 (1990) 23.

[13] A.R. Brough, C.M. Dobson, I.G. Richardson, G.W. Groves, J. Am. Ceram. Soc. 77 (1994) 593.

[14] I. Klur, B. Pollet, J. Virlet, A. Nonat, in: P. Colombet, A.-R. Grimmer, H. Zanni, P. Soozzani (Eds.), Nuclear Magnetic Resonance Spectroscopy of Cement-Based Materials, Springer, Berlin, 1998, p. 119.

[15] X. Cong, R.J. Kirkpatrick, Adv. Cem. Based Mater. 3 (1996) 144.

[16] A.R. Brough, C.M. Dobson, I.G. Richardson, G.W. Groves, J. Mater. Sci. 29 (1994) 3926.

[17] P. Faucon, J.-F. Jaquinot, F. Adenot, N. Gautier, D. Massiot, J. Virlet, in: P. Colombet, A.-R. Grimmer, H. Zanni, P. Soozzani (Eds.), Nuclear Magnetic Resonance Spectroscopy of Cement-Based Materials, Springer, Berlin, 1998, p. 403.

[18] D.S. Klimesch, G. Lee, A. Ray, M.A. Wilson, Adv. Cem. Res. 10 (1998) 93.

[19] B. Bresson, F. Méducin, H. Zanni, C. Noik, J. Mater. Sci. 37 (2002) 1 .

[20] H. Zanni, M. Cheyrezy, V. Maret, S. Philippot, P. Nieto, Cem. Concr. Res. 26 (1996) 93.

[21] C. Hall, K.L. Scrivener, Adv. Cem. Based Mater. 7 (1998) 28.

[22] J. Skibsted, H.J. Jakobsen, in: P. Colombet, A.-R. Grimmer, H. Zanni, P. Soozzani (Eds.), Nuclear Magnetic Resonance Spectroscopy of Cement-Based Materials, Springer, Berlin, 1998, p. 3.

[23] J. Skibsted, H.J. Jakobsen, C. Hall, Adv. Cem. Based Mater. 7 (1998) 57.

[24] H.F.W. Taylor, Cement Chemistry, Thomas Telford Publishing, London, 1997.

[25] C. Porteneuve, H. Zanni, C. Vernet, K.O. Kjellsen, J.P. Korb, D. Petit, Cem. Concr. Res. 31 (2001) 1887.

[26] P. Faucon, A. Delagrave, J.-C. Petit, C. Richet, J.-M. Marchand, H. Zanni, J. Phys. Chem. B 103 (1999) 7796. 